8-1989

\title{
Effects of Hypoxia and Anoxia on Survival, Energy Metabolism, and Feeding of Oyster Larvae (Crassostrea virginica, Gmelin)
}

\author{
J Widdows \\ RIE Newell \\ Roger L. Mann \\ Virginia Institute of Marine Science, rmann@vims.edu
}

Follow this and additional works at: https://scholarworks.wm.edu/vimsarticles

Part of the Aquaculture and Fisheries Commons, and the Marine Biology Commons

\section{Recommended Citation \\ Widdows, J; Newell, RIE; and Mann, Roger L., "Effects of Hypoxia and Anoxia on Survival, Energy Metabolism, and Feeding of Oyster Larvae (Crassostrea virginica, Gmelin)" (1989). VIMS Articles. 1694. https://scholarworks.wm.edu/vimsarticles/1694}




\title{
Effects of Hypoxia and Anoxia on Survival, Energy Metabolism, and Feeding of Oyster Larvae (Crassostrea virginica, Gmelin)
}

\author{
J. WIDDOWS', R. I. E. NEWELL ${ }^{2}$, AND R. MANN ${ }^{3}$ \\ ${ }^{1}$ Plymouth Marine Laboratory, Prospect Place, The Hoe. Plymouth PL1 3DH, England; ${ }^{2}$ Horn Point \\ Environmental Laboratories, University of Maryland, Box 775, Cambridge, Maryland 21613; and \\ ${ }^{3}$ Virginia Institute of Marine Science, Gloucester Point, Virginia, 23062
}

\begin{abstract}
The tolerance of Crassostrea virginica larvae to anoxia increases with developmental stage and body size. Median mortality times range from $11 \mathrm{~h}$ for prodissoconch larvae of $82 \mu \mathrm{m}$ (shell length) to $51 \mathrm{~h}$ for pediveliger larvae of $312 \mu \mathrm{m}$, and $150 \mathrm{~h}$ for juvenile oysters. Simultaneous calorimetry and respirometry showed that in response to declining oxygen tension $\left(\mathrm{P}_{\mathrm{O}_{2}}\right)$, the rates of heat dissipation and oxygen uptake by oyster larvae are maintained independent of $P_{O_{2}}$ down to low $P_{c}$ values ( $2 \mathrm{kPa}$ for prodissoconch larvae and $8 \mathrm{kPa}$ for pediveliger and juveniles). Therefore, total energy metabolism is sustained mainly by aerobic metabolism down to 2 and 4 kPa for early larval stages and juveniles, respectively. Prodissoconch larvae maintain relatively high rates of heat dissipation under anoxic conditions (34\% of normoxic rate), whereas pediveliger and juveniles lower their anoxic rates of heat dissipation to $3 \%$ of the normoxic rate. The ability to reduce rates of heat dissipation and thus conserve energy expenditure under anoxia appears to be related to the increase in anoxia tolerance with larval development. The larval differences in the relationship between $\mathrm{P}_{\mathrm{O}_{2}}$ and the rate of heat dissipation are also reflected in feeding rate (ingestion rate of microspheres). Prodissoconch larvae maintain feeding activity under anoxic conditions (29\% of normoxic ingestion rate), in contrast to pediveliger larvae, which lower ingestion rates to $5 \%$ of the normoxic rate.
\end{abstract}

\section{Introduction}

Many estuaries and bays regularly exhibit seasonal salinity and temperature stratification, which can lead to

Received 23 January 1989; accepted 30 May 1989. hypoxia and anoxia in the bottom waters. This situation is particularly pronounced in the Chesapeake Bay, where the decline in water quality over the last 25 years, caused in part by eutrophication, has contributed to a significant increase in the extent of hypoxic or anoxic waters (Taft $e t$ al., 1980; Kemp and Boynton, 1984; Officer et al., 1984; Seliger et al., 1985; Malone et al., 1986; Mackiernan, 1987). The seasonal occurrence of stratification coincides with, or partially overlaps, the period of spawning and settlement of the American oyster Crassostrea virginica (Gmelin). Although the spatial occurrence of hypoxia or anoxia is usually restricted to deeper waters, the seiching of deeper waters due to wind stress periodically irrigates the shallower areas-where oyster reefs abound-with hypoxic or anoxic water. Bivalve larvae appear to employ depth regulation to effect their retention in shallow, stratified estuaries (Wood and Hargis, 1971; Mann, 1986). Therefore, both larval and early post larval stages of the oyster may be subjected to hypoxic or anoxic stress in the Chesapeake Bay during summer months.

Adult oysters and other bivalves can survive prolonged anoxia, primarily by using glycogen in anaerobic metabolic pathways (de Zwaan, 1983). Larval stages may lack this capacity because (a) their nutrient reserves are relatively small (Mann and Gallager, 1985) and (b) polysaccharides form a relatively small proportion of their total energy reserves (Holland and Spencer, 1973). Energy reserves of larvae are primarily lipid and protein, and lipid cannot be used as a substrate for anaerobic catabolism. Consequently, early developmental stages of the oyster (Crassostrea virginica) may be particularly vulnerable to hypoxic conditions. 
Although the rate of oxygen consumption by adult oysters (Crassostrea virginica) in response to hypoxia has been studied (Shumway and Koehn, 1982), little is known about the metabolic and feeding responses of oyster larvae and juveniles ('O' group or spat) to hypoxia and anoxia, nor about their overall tolerance of anoxia.

The main objectives of this study were (a) to examine the anoxia tolerance of the larval stages and spat of $\mathrm{Cras}$ sostrea virginica, and (b) to determine their rates of metabolic energy expenditure and feeding under hypoxic and anoxic conditions. Simultaneous open-flow calorimetry and respirometry were used to measure metabolic activity of oyster larvae and spat, thus providing a partitioning of the rate of heat dissipation into aerobic and anaerobic components under normoxia, hypoxia, and anoxia (Widdows, 1987).

\section{Material and Methods}

\section{Collection and maintenance of specimens}

Oyster (Crassostrea virginica) larvae were reared and supplied by the Virginia Institute of Marine Science hatchery at Gloucester Point, Virginia; juvenile oysters (16 mm shell height) were collected from Whaley's oyster bar in the estuary of the Great Wicomico River, Virginia. All experiments were performed at $22^{\circ} \mathrm{C}$ and $12 \%$, the ambient temperature and salinity at Gloucester Point in May 1987. Larvae and juvenile oysters were maintained in static systems, receiving water changes every two days, and daily additions of algal food (Isochrysis galbana Parke) at a concentration of about $50 \times 10^{6}$ cells $1^{-1}$.

When the water was changed, larvae were separated, with a series of 'Nitex' nylon sieves, into various size classes, ranging from prodissoconch ' $D$ stage' larvae to veliconcha and pediveligers. They were then resuspended in $12 \% 0.45 \mu \mathrm{m}$ membrane filtered seawater (FSW). In addition to removing fecal material, this sieving removed the smallest size class from the larval culture, which generally included individuals that were either abnormal or dead. Only those larvae that were actively swimming in the water column were collected for an experiment.

After each experiment the larvae were sampled, and the total number of individuals, mean shell length, and dry mass (after washing in distilled water and drying at $80^{\circ} \mathrm{C}$ ) were estimated. Shell length (the maximum dimension parallel to the hinge line) was measured with a Kontron IPS image analysis system connected to a Reichert-Jung Polyvar microscope with a calibrated graticule eyepiece. In addition, relationships between shell length, dry mass, and ash-free dry mass (weight loss at $500^{\circ} \mathrm{C}$ ) were established for larvae $(60 \mu \mathrm{m}$ to $330 \mu \mathrm{m}$ shell length). They are described by the following equations:

$$
\begin{aligned}
\mathrm{DM} & =\left(2.48 \times 10^{-5}\right) \mathrm{SL}^{2.073}(\mathrm{r}=0.96) \\
\mathrm{AFDM} & =\left(9 \times 10^{-6}\right) \mathrm{SL}^{2.066}(\mathrm{r}=0.94)
\end{aligned}
$$

where DM is the total dry mass $(\mu \mathrm{g}), \mathrm{AFDM}$ is the ash free dry mass $(\mu \mathrm{g})$, SL is shell length $(\mu \mathrm{m})$. Each equation is based on larvae from 10 different size classes for which the mean SL of 10 individuals was measured and the DM and AFDM of a pool of 25 larvae was determined.

Juvenile oysters (spat) of $16 \mathrm{~mm}$ shell height (i.e., maximum dimension from the hinge to the ventral margin) were thoroughly cleaned of epibionts; the shells were first scrubbed and the surfaces were then cleaned with $1 \% \mathrm{~V}$ : V sodium hypochlorite (Newell, 1985). Before being exposed to hypoxia and anoxia, the spat were maintained overnight in tanks with flowing seawater $(12 \%)$, and ambient seston concentrations to establish that they were actively feeding and producing biodeposits. After measuring physiological responses, we removed body tissues from the shell and dried them at $80^{\circ} \mathrm{C}$ before weighing.

\section{Anoxia survival experiments}

Three size classes of larvae, representing prodissoconch ' $D$ ' stage, veliconch, and pediveligers $(82 \mu \mathrm{m} \pm 2$, $167 \mu \mathrm{m} \pm 3$ and $312 \mu \mathrm{m} \pm 2$; mean \pm S.E. of shell length, respectively) and juvenile oysters (16 $\mathrm{mm}$ shell height), were selected for study in the anoxia tolerance experiments. Larvae were introduced into $5 \mathrm{ml}$ glass syringes (100-200 larvae per syringe) and any gas bubbles were removed. A syringe filter holder containing a $20 \mu \mathrm{m}$ 'Nitrex' mesh was attached to the syringe to retain the larvae as the volume of water in the syringe was reduced to 0.4 $\mathrm{ml}$. The syringe and filter holder were then attached to a stainless steel needle that passed through a small silicone stopper at the base of a glass reservoir (1 1). The reservoir, containing $12 \% \mathrm{FSW}$, was deoxygenated by a continuous fine stream of high purity nitrogen gas (delivered via stainless steel tubing) for at least $2 \mathrm{~h}$ prior to sampling. The syringe was slowly filled with $5.5 \mathrm{ml}$ of anoxic FSW, detached from the reservoir together with the 'Nitex' filter, and the water was then slowly expelled through the filter, reducing the volume to $0.4 \mathrm{ml}$ while retaining the larvae. This procedure was repeated five times to ensure that the final $5.5 \mathrm{ml}$ of water in the syringe was anoxic at the start of the anoxia tolerance experiments.

The partial pressure of oxygen in the reservoir of FSW and in the final volume contained within the glass syringes was measured with a Radiometer oxygen electrode (E5046) held in a thermostatted cell and coupled to a Radiometer oxygen meter and chart recorder. The electrode was calibrated daily with air-saturated water and oxygen-zero solution (Radiometer 54150).

The experimental procedures described above consistently maintained anoxic conditions (i.e., oxygen con- 
centrations in the syringes were typically zero and were always $<0.2 \%$ of full air saturation and not significantly above the detection limit).

Syringes containing the larvae were sealed by inserting the stainless steel needles into a silicone stopper and incubated at $22^{\circ} \mathrm{C}$ in a water bath for up to three days. At intervals during the anoxia exposure period, syringes were removed and the anoxia confirmed with the oxygen sensor. The water containing the larvae was then gently reoxygenated by a stream of air bubbles for $30 \mathrm{~min}$, and the larvae observed on a Sedgewick-Rafter slide under a microscope. Mortality of the larvae, defined as the absence of any ciliary activity after $30 \mathrm{~min}$ of normoxia, was expressed as percentage of the total number of animals. There was no evidence of further recovery after this 30-min recovery period.

Actively feeding juvenile oysters were selected and placed in 12\% FSW in $200 \mathrm{ml}$ glass containers (10 individuals per container). The containers were sealed with stoppers through which passed glass tubes for the entry and exit of high purity nitrogen gas. The contents of each container were deoxygenated for one hour and then the tubes were sealed. All containers were placed in a large glass desiccator continuously purged by a stream of nitrogen gas to prevent any diffusion of oxygen through the stoppers. Samples of water from a sealed control container were analyzed, confirming anoxic conditions. After 3 days of anoxia and daily thereafter (i.e., 3-8 days of anoxia), 10 juvenile oysters were removed from sealed containers and placed in flowing aerated seawater $(12 \%)$ with ambient seston concentrations. Mortality was judged by the failure to close the shell when stimulated, and the absence of feeding activity and production of biodeposits during $24 \mathrm{~h}$ of recovery in air-saturated seawater with natural suspended particulates.

\section{Measurement of rate of heat dissipation and oxygen uptake in relation to hypoxia or anoxia}

Rates of metabolic energy expenditure by oyster larvae and juveniles were measured by open-flow simultaneous calorimetry and respirometry at the Plymouth Marine Laboratory (U. K.). Larvae or juveniles (from Virginia) were placed in a $25 \mathrm{ml}$ stainless steel chamber modified for use as a perfusion chamber in a microcalorimeter (LKB, BioActivity Monitor). Membrane filtered (0.45 $\mu \mathrm{m})$ seawater $\left(22^{\circ} \mathrm{C} ; 12 \%\right.$ salinity) was pumped through the perfusion chamber in the calorimeter at a constant flow rate [i.e., 28,37 , or $62 \mathrm{ml} \mathrm{h}^{-1}( \pm 0.5)$ depending upon the biomass within the chamber] and then to a thermostatted Radiometer oxygen sensor via $1 \mathrm{~mm}$ bore stainless steel tubing. A duplicate calorespirometric system, without larvae, was a reference for monitoring base- line heat flow and inflow oxygen concentrations (for further details see Widdows, 1987). The exit ports of the perfusion chambers were fitted with $37 \mu \mathrm{m}$ mesh to retain the larvae within the chamber. Rates of oxygen uptake by the larvae were calculated from the differences in the oxygen concentration of the outflows from the reference and experimental chambers (at a known flow rate). Flow rates of 28,37 , and $62 \mathrm{ml} \mathrm{h}^{-1}$ were selected to achieve approximately $15 \%$ removal of oxygen from the inflowing water and to enable experimental manipulation of $\mathrm{P}_{\mathrm{O}_{2}}$.

Preliminary calorimetric and respirometric measurements of larvae in the presence of algal food (Isochrysis galbana) demonstrated a significant drift in the baselines for heat flow and oxygen concentration over a $24-\mathrm{h}$ period, presumably due to the attachment of cells to the surfaces and increasing microbial activity within the system. Consequently, larvae were maintained unfed in FSW during the period of measurement. An additional time-course study demonstrated that there was no significant alteration in rates of heat dissipation and oxygen uptake by 'unfed' larvae in fully air-saturated FSW over a $24-\mathrm{h}$ period in the calorimeter.

The effects of hypoxia and anoxia on the metabolic rate of three larval stages $(99 \mu \mathrm{m}, 133 \mu \mathrm{m}$ and $>300$ $<376 \mu \mathrm{m}$ shell length) and juvenile oysters ( $16 \mathrm{~mm}$ shell height) were measured by open-flow simultaneous calorimetry and respirometry. Larvae were sieved from their respective cultures, concentrated, and placed in the perfusion chamber. The number of individuals within the chamber varied with larval size ( 14 to $20 \times 10^{3}$ for $99 \mu \mathrm{m}$ larvae, $12 \times 10^{3}$ for $133 \mu \mathrm{m}$ larvae and 2 to $4 \times 10^{3}$ for $>300-<376 \mu \mathrm{m}$ larvae), whereas the juvenile oysters were measured as individuals. The number of prodissoconch larvae available was only sufficient for three groups of $99 \mu \mathrm{m}$ larvae and one group of $133 \mu \mathrm{m}$ larvae to be measured by calorespirometry, whereas six groups of $>300-<376 \mu \mathrm{m}$ larvae and five individual juvenile oysters were measured.

The calorespirometric system established an equilibrium within $3 \mathrm{~h}$ and the rates of heat dissipation and oxygen uptake under normoxic conditions (fully air-saturated) were continuously monitored overnight (about 8 h). By increasing the proportion of nitrogen gas to air the $\mathrm{P}_{\mathrm{O}_{2}}$ in the reservoir of FSW was reduced step-wise through 8,4 , and $2 \mathrm{kPa}(60,30$, and $15 \mathrm{~mm} \mathrm{Hg})$. These levels of hypoxia were maintained for a period of $2-3 \mathrm{~h}$ to establish steady-state conditions of heat flow and $\mathrm{P}_{\mathrm{O}_{2}}$. Below $2 \mathrm{kPa}$, only oxygen-free nitrogen gas was bubbled into the reservoir. This gradually reduced the $\mathrm{P}_{\mathrm{O}_{2}}$ to zero over $6 \mathrm{~h}$.

After each experimental run, the calorespirometric system was cleaned with $10 \% \mathrm{~V}: \mathrm{V}$ sodium hypochlorite 
solution, thoroughly washed with distilled water, and its baseline checked before the next experimental run.

An additional group of juvenile oysters was held at $15^{\circ} \mathrm{C}$ and fed Isochrysis galbana for 14 days before measuring the rate of oxygen uptake in air-saturated water $(12 \%)$. To quantify the emersed anoxic rate of heat dissipation, these individuals were transferred to the calorimeter chamber, which was purged with nitrogen gas.

\section{Measurement of ingestion rate in response to hypoxia and anoxia}

Ingestion rates by prodissoconch $(>73-<140 \mu \mathrm{m})$ and pediveliger $(>300-<376 \mu \mathrm{m}$ ) larvae during exposure to hypoxia and anoxia were quantified using $3.44 \mu \mathrm{m}$ diameter 'Fluoresbrite' polystyrene fluorescent microspheres (Polyscience Inc.). To encourage their phagostimulatory nature, the microspheres were added to autoclaved $12 \%$ seawater containing an algal extract. This was prepared from a pellet of Isochrysis galbana cells that had been homogenized and centrifuged to remove cell debris.

The experimental protocol involved allowing about 50 larvae to filter and ingest the microspheres for $10 \mathrm{~min}$ under controlled partial pressures of oxygen, as described below. After the exposure period, further ingestion of microspheres was prevented by fixing the larvae in $4 \%$ buffered formaldehyde. Preliminary experiments demonstrated that fixation did not cause the larvae to egest or defecate any of the microspheres within the digestive system. Larvae were then washed three times in distilled water to remove loose microspheres and stored in $4 \%$ buffered formaldehyde.

The number of microspheres ingested was counted using an inverted microscope fitted with a fluorescence light source. The prodissoconch larvae had a sufficiently small gut and thin shell that the number of ingested microspheres could be counted directly. However, for the pediveligers, especially those that were actively feeding under normoxic conditions, the microspheres aggregated within the digestive system such that they could not be enumerated. For these heavily feeding larvae the percentage of individuals feeding was initially determined from the entire group. From this group, about 50 randomly selected individual larvae were transferred, using a micropippette, to wells of a flat-bottomed tissue culture plate. After the water had been evaporated at $40^{\circ} \mathrm{C}$, $10 \mu \mathrm{l} \mathrm{HCl}$ was added to each well to dissolve the larval shell. The acid was then evaporated and $30 \% \mathrm{H}_{2} \mathrm{O}_{2}$ added to dissolve most of the tissue. This digestion and disruption process was enhanced by placing the plates in a Brinkman sonicator bath. The microspheres at the bottom of each well were then counted on the inverted microscope after the $\mathrm{H}_{2} \mathrm{O}_{2}$ had evaporated. Preliminary ex- periments determined that these treatments did not alter the particle fluorescence or size.

The fluorescent microsphere method of assessing larval feeding rates was compared to a traditional method of measuring suspension feeding activity that involves estimating the logarithmic decline in algal cell concentration over time (Coughlan, 1969). In this comparative experiment, 1500 pediveliger larvae were maintained for 3 $\mathrm{h}$ in 3 replicate $250 \mathrm{ml}$ flasks containing Isochrysis galbana at a concentration of $30 \times 10^{6}$ cells $1^{-1}$. The initial algal cell concentration was counted using a Coulter Counter and again at hourly intervals for each of the replicates. From this, a mean filtration rate of $54.1 \pm 7.8$ (S.E.) $\mu \mathrm{l} \mathrm{h}^{-1}$ individual $^{-1}$ was estimated. Filtration rate was measured using the microsphere method for 100 individual larvae from the same culture, measured at the same time. The rate was $66.2 \pm 21.3$ (S.E.) $\mu \mathrm{l} \mathrm{h}^{-1}$ individ$\mathrm{ual}^{-1}$. This indicates that the use of algal cells and microspheres gave comparable filtration rates. The larger variance associated with the microsphere method reflects the examination of 100 individual larvae. However, to obtain a measurable decrease in algal cell concentration by the Coulter Counter method, many larvae are required in each flask. This masks any high individual variability in the feeding activity of larvae.

Larvae were exposed to anoxic conditions in $5 \mathrm{ml}$ glass syringes using the procedure described above (anoxia survival experiments). Ten minutes before the end of the incubation period, the anoxic seawater in the syringe was replaced by anoxic seawater containing fluorescent microspheres at a concentration of $18 \times 10^{6} 1^{-1}$.

Larvae were exposed to hypoxic conditions in $5 \mathrm{ml}$ vials through which $22^{\circ} \mathrm{C}$ water of the appropriate partial pressure of oxygen was pumped $\left(50 \mathrm{ml} \mathrm{h}^{-1}\right)$ from a reservoir. Isochrysis galbana cells $\left(20 \times 10^{6}\right.$ cells $\left.1^{-1}\right)$ were added to the reservoir, providing the larvae with a source of food. This ensured that the ingestion rate measured with the microspheres was a typical steady state value and was not an enhanced rate due to rapid gut filling by starved larvae suddenly presented with particles.

Ingestion rates in relation to exposure time were measured at three different levels of hypoxia $(0.8-1.7 \mathrm{kPa}$, 2.2-3.0 kPa, and 4.0-5.6 kPa) and compared to ingestion rates by larvae at full air saturation $(21 \mathrm{kPa})$. The partial pressures of oxygen within the reservoir was controlled by regulating the flows of nitrogen and compressed air; $\mathrm{P}_{\mathrm{O}_{2}}$ was not maintained at an absolute level, but only within the stated ranges. The outflow from the $5 \mathrm{ml}$ vials was passed through the Radiometer flow cell to provide a continuous record of the $\mathrm{P}_{\mathrm{O}_{2}}$. Ten minutes before the exposure period was complete, the flow was stopped and $10 \mu \mathrm{l}$ of concentrated suspension of microspheres was injected through a silicone septum in the top 

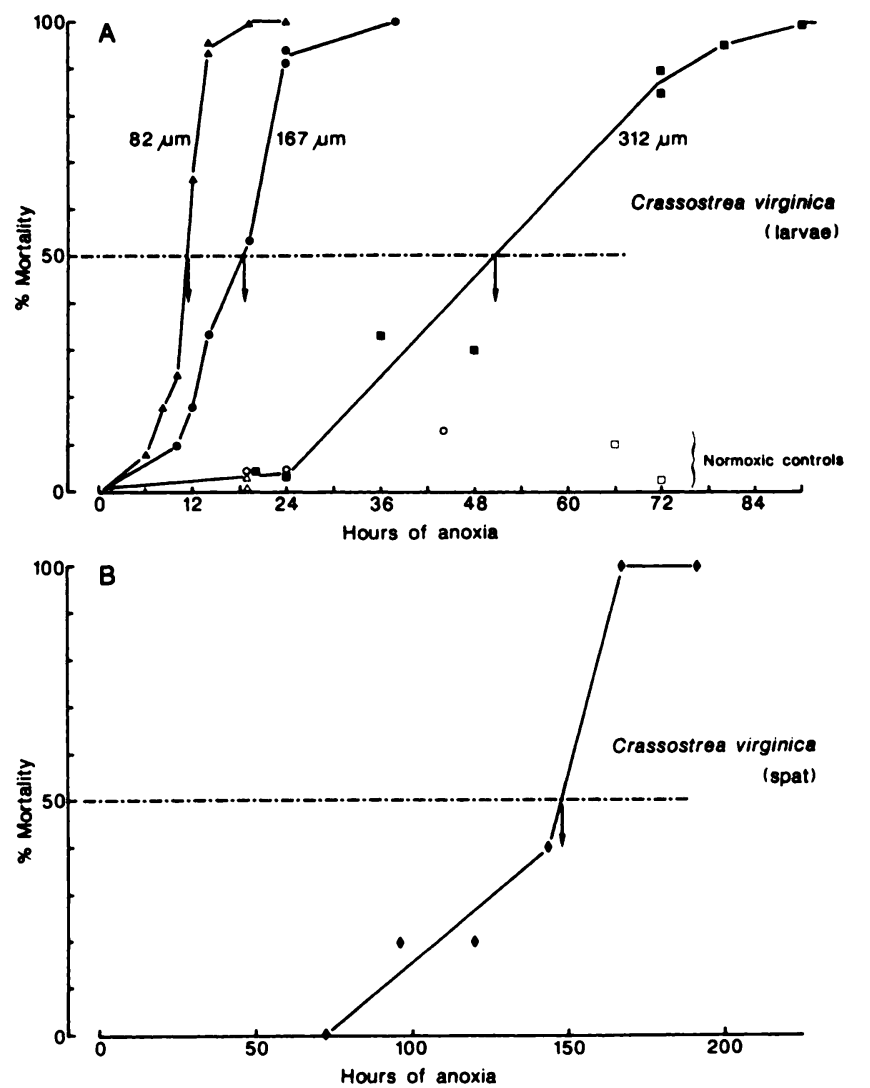

Figure 1. Relationship between mortality and duration of anoxia for (A) larval stages ( $\Delta$ prodissoconch, $\bullet$ veliconcha, $\square$ pediveliger) and (B) juvenile or spat $(\diamond)$ of Crassostrea virginica. Open symbols represent level of mortality in the respective controls.

of each vial to give a final concentration of $18 \times 10^{6} \mathrm{mi}-$ crospheres $1^{-1}$. Following a 10 -min incubation with microspheres, the larvae were sampled and the ingestion rate quantified using the procedures described above. Additional vials of larvae were prepared in order to examine the ability of pediveliger larvae to recover from 24 $h$ of exposure to hypoxic conditions. The rate of ingestion of microspheres by larvae was then measured following the return of water to full air-saturation.

\section{Results}

\section{Anoxia tolerance}

Anoxic tolerance of Crassostrea virginica increased with developmental stage and body size (Fig. 1). The median mortality time (MMT; i.e., the time required to reach a $50 \%$ mortality) was approximately 11,18 , and 51 $\mathrm{h}$ for the three larval stages $(82 \mu \mathrm{m}$ prodissoconch, 167 $\mu \mathrm{m}$ veliconcha, and $312 \mu \mathrm{m}$ pediveliger, respectively). The MMT for the juvenile oysters was about $150 \mathrm{~h}$. There was close agreement among replicates, and the normoxic controls typically showed only $6-10 \%$ mortality at the time of total mortality in the experimental (anoxic) groups. During the initial phase of anoxia, we observed that the larvae maintained swimming activity for at least 30 to $60 \mathrm{~min}$ before settling to the bottom of the syringe.

\section{Effect of hypoxia and anoxia on the rate of heat dissipation and oxygen uptake}

The effect of a reduction in the partial pressure of oxygen $\left(\mathrm{P}_{\mathrm{O}_{2}}\right)$ on the rate of heat dissipation $(\dot{\mathrm{Q}})$ and oxygen uptake $\left(\dot{\mathrm{N}}_{\mathrm{O}_{2}}\right)$ by the three larval stages $(99,133$, and 300 $376 \mu \mathrm{m})$ and juveniles are shown in Figures $2 \mathrm{~A}-\mathrm{D}$, respectively. The results demonstrate that the metabolic rate of larvae declined at reduced $\mathrm{P}_{\mathrm{O}_{2}}$ values and the response to short-term hypoxia and anoxia (i.e., duration of several hours) changed with body size or developmental stage.

The prodissoconch larvae (Fig. 2A) maintained their rates of heat dissipation and oxygen uptake independent of $\mathrm{P}_{\mathrm{O}_{2}}$ down to $2 \mathrm{kPa}$ ( $15 \mathrm{~mm} \mathrm{Hg}$ ), whereas the larger larvae (Fig. 2B, C) and juveniles (Fig. 2D) maintained their rates of heat dissipation and oxygen uptake down to only about $8 \mathrm{kPa}$ (Table I). Below this $\mathrm{P}_{\mathrm{O}_{2}}$, generally referred to as the critical oxygen partial pressure $\left(P_{c}\right)$ (Herreid, 1980), the rates of heat dissipation and oxygen uptake become dependent upon $\mathrm{P}_{\mathrm{O}_{2}}$. Table $\mathrm{I}$ also includes the oxygen partial pressure that results in a reduction in the heat dissipation rate to $50 \%$ of the normoxic and typically maximum rate. The $\mathrm{P}_{\mathrm{O}_{2}}$ at $0.5 \dot{\mathrm{Q}}_{\text {normoxia }}$ was only $0.27 \mathrm{kPa}$ for $99 \mu \mathrm{m}$ larvae, increasing to $2.4 \mathrm{kPa}$ for the 133 and $300-376 \mu \mathrm{m}$ larvae and $3.1 \mathrm{kPa}$ for the juveniles. These results indicate that the larvae, especially the early larval stage $(99 \mu \mathrm{m})$, can maintain their total metabolic rate down to low $\mathrm{P}_{\mathrm{O}_{2}}$ values. Furthermore, a comparison of the rates of heat dissipation and oxygen uptake (Fig. 2A-D) shows that oxygen consumption continues even at low $\mathrm{P}_{\mathrm{O}_{2}}$ and forms a significant component of the total metabolic rate.

The oxycaloric equivalent in aerobic catabolism ranges from -440 to $-480 \mathrm{~kJ} \mathrm{~mol}^{-1} \mathrm{O}_{2}$ in aquatic animals (Gnaiger, 1983). When experimentally derived oxycaloric equivalent values exceed the range of theoretical values, then partial anaerobiosis is indicated. The higher the experimental oxycaloric value the greater the reliance on anaerobic metabolism. Experimental oxycaloric equivalent values, which can be derived from the calorespirometric measurements, are presented in Table II. The values under normoxia $(20.5 \mathrm{kPa})$ and above 2 $\mathrm{kPa}$ were not significantly different from the theoretical range of oxycaloric equivalents, commonly used to convert rates of oxygen consumption into rates of catabolic 

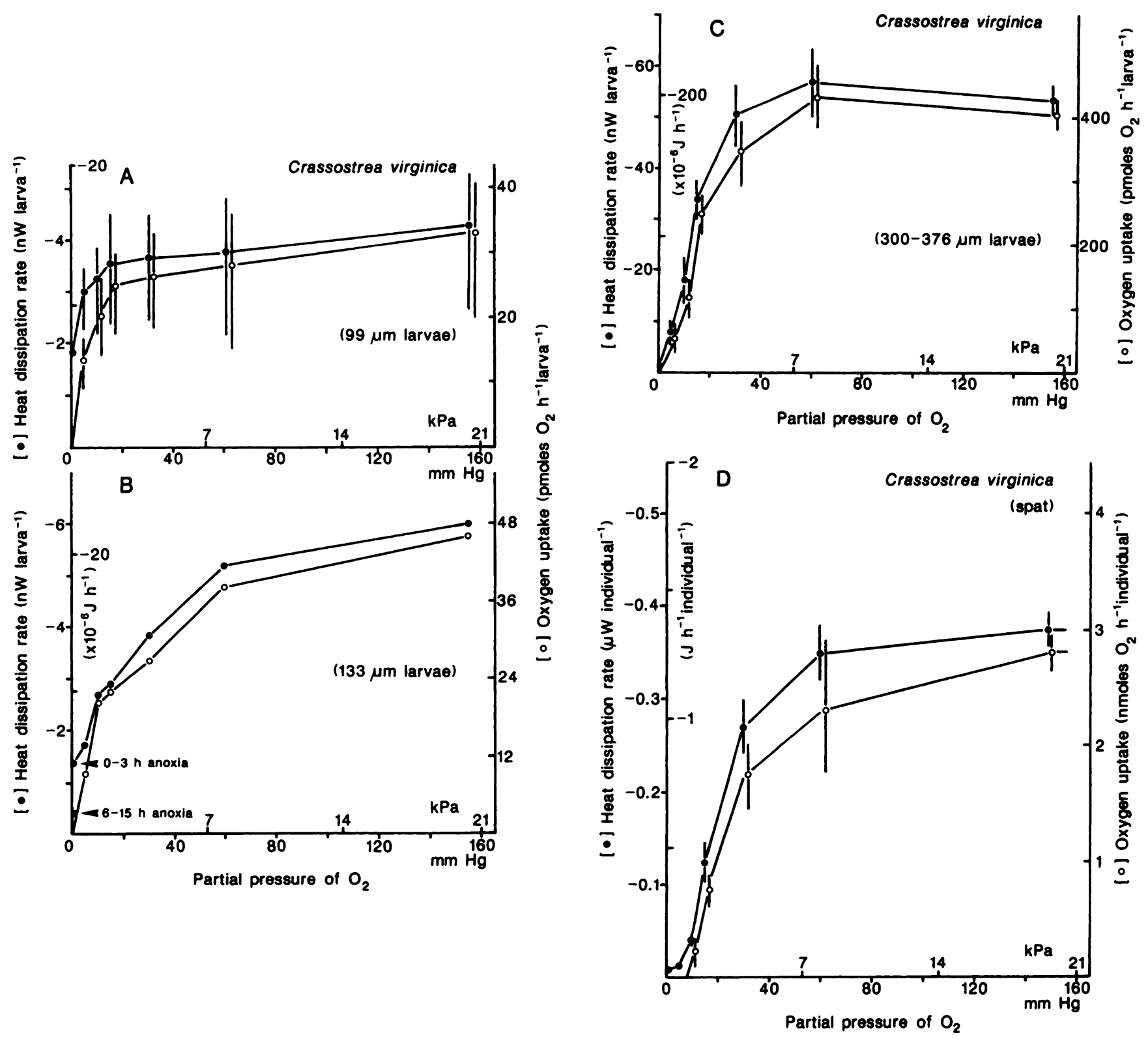

Figure 2. Effect of partial pressure of oxygen on rates of heat dissipation $(0)$ and oxygen uptake $(O)$ by prodissoconch larvae (A, means \pm range; $n=3$ ); veliconch larvae $(B)$; pediveligers $(C$, mean $\pm S . E . ; n=5$ ) and juveniles $(D$, mean \pm S.E.; $n=5)$ of Crassostrea virginica. The rates of heat dissipation and oxygen uptake are plotted on corresponding scales using an oxycaloric equivalent of $-450 \mathrm{~kJ} \mathrm{~mol}_{2}{ }^{-1}$ (or $1 \mathrm{nmoles}$ $\mathrm{O}_{2} \mathrm{~h}^{-1}=-0.125 \mu \mathrm{W}$; Gnaiger, 1983).

heat dissipation. However, the results indicate that the experimental oxycaloric equivalents were slightly above the theoretical range at many $\mathrm{P}_{\mathrm{O}_{2}}$ levels. This may be due to the valve closure and quiescence of a proportion of the larvae and their reliance on anaerobic metabolism. At the lowest $\mathrm{P}_{\mathrm{O}_{2}}$ level $(0.67 \mathrm{kPa})$, the rate of heat dissipation by all larval stages had a significant anaerobic component, and $40 \%$ of the juveniles were closed and totally anaerobic. At 1.33 and $2 \mathrm{kPa}$ the juveniles also had a significant (ANOVA; $P<0.05$ ) anaerobic contribution to the total heat dissipation.

In Table I, the anoxic rates of heat dissipation $\left(\dot{Q}_{\text {anoxia }}\right)$ during the initial $3 \mathrm{~h}$ of anoxia are expressed as a proportion of the normoxic rates of heat dissipation $\left(\dot{\mathbf{Q}}_{\text {normoxia }}\right)$. The $99 \mu \mathrm{m}$ and $133 \mu \mathrm{m}$ larvae had relatively high values, which were $34 \%$ and $23 \%$ of $\dot{Q}_{\text {normoxia }}$, respectively. However, after $6 \mathrm{~h}$ of anoxia, the $Q_{\text {anoxia }}$ of $133 \mu \mathrm{m}$ larvae declined to $7 \%$ of $\dot{\mathrm{Q}}_{\text {normoxia }}$ and was maintained at this 
Table I

Descriptors of the effect of oxygen partial pressure $\left(P_{o_{2}}\right)$ on the metabolic rate of three sizes of oyster (Crassostrea virginica) larvae and juveniles

\begin{tabular}{|c|c|c|c|c|c|}
\hline & \multirow[b]{2}{*}{ Size: } & \multicolumn{3}{|c|}{$\begin{array}{l}\text { Oyster larvae } \\
\text { (Shell length) }\end{array}$} & \multirow{2}{*}{$\begin{array}{c}\begin{array}{c}\text { Spat } \\
\text { (Shell height) }\end{array} \\
16 \mathrm{~mm}\end{array}$} \\
\hline & & $99 \mu \mathrm{m}$ & $133 \mu \mathrm{m}$ & $>300-<376 \mu \mathrm{m}$ & \\
\hline $\begin{array}{l}\mathrm{P}_{\mathrm{c}}(\mathrm{kPa})^{\mathrm{a}} \\
\mathrm{P}_{\mathrm{O}_{2}}(\mathrm{kPa}) \text { at } 0.5 \dot{\mathrm{Q}}_{\text {(normoxia) }}{ }^{\mathrm{b}} \\
\mathrm{P}_{\mathrm{O}_{2}}(\mathrm{kPa}) \text { at } 0.5 \dot{\mathrm{N}}_{\mathrm{O}_{2} \text { (normoxia) }} \\
\dot{\mathrm{Q}}_{\text {anoxia }}{ }^{\mathrm{C}} \dot{\mathrm{Q}}_{\text {normoxia }}\end{array}$ & & $\begin{array}{l}2 \\
0.27 \\
1.05 \\
0.34\end{array}$ & $\begin{array}{l}8 \\
2.4 \\
2.4 \\
0.23\end{array}$ & $\begin{array}{l}8 \\
2.3 \\
2.3 \\
0.05\end{array}$ & $\begin{array}{l}8 \\
3.1 \\
3.5 \\
0.03\end{array}$ \\
\hline
\end{tabular}

- $\mathrm{P}_{\mathrm{c}}$-critical oxygen partial pressure ( $\mathrm{P}_{\mathrm{O}_{2}}$ below which $\dot{\mathrm{Q}}$ and $\dot{\mathrm{N}}_{\mathrm{O}_{2}}$ become $\mathrm{P}_{\mathrm{O}_{2}}$ dependent).

${ }^{b} \mathrm{PO}_{2}$ at $0.5 \mathrm{Q}_{\text {normoxis }}-\mathrm{PO}_{2}$ that reduces rate of heat dissipation to $50 \%$ of normoxic (maximum) rate.

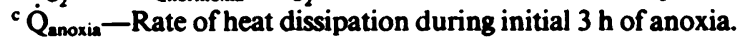

level for $15 \mathrm{~h}$. In contrast, the pediveliger (300-376 $\mu \mathrm{m})$ and the juveniles had relatively lower $Q_{\text {anoxia }}, 5 \%$ and $3 \%$ of $\dot{Q}_{\text {normoxia }}$. After $5 \mathrm{~h}$ of anoxia, the $\dot{\mathrm{Q}}_{\text {anoxia }}$ of the pediveliger declined from $5 \%$ to $2 \%$ of $\dot{\mathrm{Q}}_{\text {normoxia }}$, and was maintained at this level for $10 \mathrm{~h}$.

Juvenile oysters were also held at $15^{\circ} \mathrm{C}$ and their rates of oxygen uptake (under normoxia) and heat dissipation (under anoxia, $\mathrm{N}_{2}$ gas) were measured independently at $15^{\circ} \mathrm{C}$. The results (Table III) show that $\dot{Q}_{\text {anoxia }}$ at $15^{\circ} \mathrm{C}$ was $5 \%$ of the normoxic rate of energy expenditure, which is not significantly different (ANOVA) from the $\dot{Q}$ anoxia at $22^{\circ} \mathrm{C}$ (i.e., $\mathrm{Q}_{10} \sim 1$ ). In contrast, the rate of oxygen uptake increased significantly with temperature, $\left(Q_{10}\right.$ $=2.28$ ).

\section{Recovery from anoxia}

On three occasions, groups of pediveliger larvae $(>300-<376 \mu \mathrm{m})$ were recovered after $>11 \mathrm{~h}$ of anoxia.
The $\mathrm{P}_{\mathrm{O}_{2}}$ in the calorespirometric chamber was allowed to rise rapidly to normoxic levels while rates of heat dissipation and oxygen uptake were being monitored continuously. In each case, the response was a very rapid rise in both heat dissipation and oxygen uptake rates (Fig. 3). Due to the rapid changes in rates of heat dissipation under these conditions the apparent rate was converted to the instantaneous rate (Gnaiger, 1983), using an exponential delay correction (i.e., $10 \mathrm{~min}$ time constant for the calorimetric system). In contrast to the slight overshoot $(32 \%)$ in the rate of heat dissipation, the larvae showed a marked overshoot ( $\mathrm{ca} .300 \%)$ in the rate of oxygen uptake (termed the oxygen debt payment). Oxygen uptake by the larvae returned to a near steady rate after 2-3 $\mathrm{h}$. The mean oxycaloric equivalent during the first hour was $-180 \mathrm{~kJ} \mathrm{~mol}^{-1} \mathrm{O}_{2}$ and increased to $-377 \mathrm{~kJ}$ $\mathrm{mol}^{-1} \mathrm{O}_{2}$ and $-500 \mathrm{~kJ} \mathrm{~mol}^{-1} \mathrm{O}_{2}$ after 2 and $3 \mathrm{~h}$, respectively. This was followed by a period (3-6 $\mathrm{h}$ recovery) when the oxycaloric equivalent was maintained at -583

Table II

Experimental oxycaloric equivalents ( $\mathrm{kJ} \mathrm{mol}^{-1} \mathrm{O}_{2}$; derived by simultaneous calorimetry and respirometry) describing the nature of energy metabolism of oyster (Crassostrea virginica) larvae and juveniles

\begin{tabular}{|c|c|c|c|c|}
\hline \multirow[b]{3}{*}{$\mathrm{P}_{\mathrm{O}_{2}}(\mathrm{kPa})$} & \multicolumn{3}{|c|}{$\begin{array}{l}\text { Oyster larvae } \\
\text { (Shell length) }\end{array}$} & \multirow{3}{*}{$\frac{\begin{array}{c}\text { Spat } \\
\text { (Shell height }\end{array}}{16 \mathrm{~mm}}$} \\
\hline & Size: $99 \mu \mathrm{m}$ & $133 \mu \mathrm{m}$ & $>300-<376 \mu \mathrm{m}$ & \\
\hline & \multicolumn{3}{|c|}{ Oxycaloric equivalents $\left(\mathrm{kJ} \mathrm{mol}^{-1} \mathrm{O}_{2}\right)$} & \\
\hline 20.5 & $-450 \pm 14^{\prime \prime}$ & -477 & $-469 \pm 11^{b}$ & $-486 \pm 5^{b}$ \\
\hline 4 & $-505 \pm 33$ & -524 & $-548 \pm 53$ & $-508 \pm 15$ \\
\hline 2 & $-504 \pm 57$ & -462 & $-490 \pm 22$ & $-616 \pm 21$ \\
\hline 1.33 & $-584 \pm 41$ & -472 & $-549 \pm 37$ & $-658 \pm 46$ \\
\hline 0.67 & $-694 \pm 54$ & -644 & $-598 \pm 50$ & $\alpha$ \\
\hline 0 & $\alpha$ & $\alpha$ & $\alpha$ & $\alpha$ \\
\hline
\end{tabular}

- Mean \pm range for $99 \mu \mathrm{m}$ larvae.

${ }^{b}$ Mean \pm S.E. for $300-376 \mu \mathrm{m}$ larvae and spat. 
Table III

Comparison between anoxic and normoxic metabolic rates (mean \pm S.E.) by juveniles of Crassostrea virginica (30 mg dry tissue mass) at $15^{\circ} \mathrm{C}(n=9)$ and $22^{\circ} \mathrm{C}(n=5)$

\begin{tabular}{lcc}
\hline \hline & $15^{\circ} \mathrm{C}$ & \multicolumn{1}{c}{$22^{\circ} \mathrm{C}$} \\
\hline $\begin{array}{l}\text { Normoxia } \\
\text { Respiration rate }\left(\mu \mathrm{moles} \mathrm{O}_{2} \mathrm{~h}^{-1}\right)\end{array}$ & $1.564 \pm 0.144$ & $2.789 \pm 0.152$ \\
$\quad$ Respiration rate $\left(\mathrm{J} \mathrm{h}^{-1}\right)$ & $0.713 \pm 0.066$ & $1.360 \pm 0.071$ \\
$\begin{array}{l}\text { Anoxia } \\
\quad \text { Heat dissipation rate }\left(\mathrm{J} \mathrm{h}^{-1}\right)\end{array}$ & $0.037 \pm 0.005$ & $0.035 \pm 0.005$ \\
$\begin{array}{l}\text { Anoxic rate as a proportion of } \\
\text { normoxic rate }\end{array}$ & 0.05 & 0.03 \\
\hline
\end{tabular}

$\mathrm{kJ} \mathrm{mol} \mathrm{O}_{2}$ and then declined to $-486 \mathrm{~kJ} \mathrm{~mol}^{-1} \mathrm{O}_{2}$ after $6 \mathrm{~h}$.

\section{Effect of hypoxia and anoxia on the rate of ingestion}

The general response of prodissoconch and pediveliger larvae to hypoxia and anoxia was a reduction in the proportion of the larvae actively feeding and ingesting microspheres over $24 \mathrm{~h}$ exposure, and a marked decline in the rate of ingestion of microspheres within the initial 2$3 \mathrm{~h}$ (Fig. 4A-D; Fig. 5A-D). Although the data for prodissoconch larvae were more variable, with the percentage of larvae feeding being inexplicably depressed at certain times (e.g., control or time zero and $2.75 \mathrm{~h}$ for $\mathrm{P}_{\mathrm{O}_{2}}$ of 4.0-5.6 kPa, Fig. $4 \mathrm{~A} ; 2.25 \mathrm{~h}$ and $4 \mathrm{~h}$ for $\mathrm{P}_{\mathrm{O}_{2}}$ of $0.8-1.7$ $\mathrm{kPa}$, Fig. $4 \mathrm{C}$ ), the reduction in the rate of ingestion was small compared to the reduction shown by pediveligers under hypoxic conditions. The ingestion rates by prodissoconch larvae were generally between 5 and 8 microspheres larva ${ }^{-1}$ per 10 min under normoxic conditions. Ingestion rates declined to about 2 microspheres lar$\mathrm{va}^{-1} 10 \mathrm{~min}^{-1}$ after $2-3 \mathrm{~h}$ of hypoxia $(<5.6 \mathrm{kPa})$ and these rates were then maintained for the $24 \mathrm{~h}$ of exposure to hypoxia (Figs. 4A-D). However, prodissoconch larvae exposed to anoxia showed no evidence of ingestion after $10 \mathrm{~h}$ of anoxia (Fig. 4D).

Pediveligers also showed a gradual decline in the proportion of larvae ingesting microspheres with increasing duration of exposure to hypoxic and anoxic conditions (Figs. 5A-D). Under normoxia (21 kPa), the pediveligers were more consistent in their feeding activity compared to the prodissoconch stage larvae. More than $60 \%$ were actively feeding and ingesting under normoxia, and the proportion of inactive larvae increased with the duration of exposure and the degree of hypoxia. For example, $\leqq 20 \%$ were feeding and ingesting after: $14 \mathrm{~h}$ at $4-5.6 \mathrm{kPa}$, $7 \mathrm{~h}$ at $2.2-3 \mathrm{kPa}, 4 \mathrm{~h}$ at $0.8-1.7 \mathrm{kPa}$, and $<1 \mathrm{~h}$ at $0 \mathrm{kPa}$
(Figs. 5A-D). The rates of ingestion by pediveligers under fully air-saturated conditions (controls, time zero) were always above 40 microspheres larva ${ }^{-1} 10 \mathrm{~min}^{-1}$, whereas under hypoxic conditions $(<5.6 \mathrm{kPa})$ the mean ingestion rate was always $<14$ microspheres $\operatorname{larva}^{-1} 10$ $\mathrm{min}^{-1}$. However, even after $24 \mathrm{~h}$ at a $\mathrm{P}_{\mathrm{O}_{2}}$ of $0.8-1.7 \mathrm{kPa}$, $4 \%$ of the larvae had ingested an average of 5 microspheres larva ${ }^{-1} 10 \mathrm{~min}^{-1}$. Visual observations suggested that in all conditions, the larvae exhibited some degree of activity that generally involved moving or swimming at or near the bottom of the experimental chamber.

After $24 \mathrm{~h}$ exposure to the three levels of hypoxia (i.e., 4-5.6, 2.2-3.0, 0.8-1.7 kPa), pediveliger larvae were allowed to recover under normoxic conditions in the presence of food before measuring their ingestion rates. A high proportion ( $>60 \%$ ) of larvae recovered after $24 \mathrm{~h}$ at $\mathrm{P}_{\mathrm{O}_{2}}$ 4-5.6 $\mathrm{kPa}$ and showed signs of feeding, but their ingestion rates had recovered only partially $(22 \%$ of the pre-exposure rate). Larvae exposed to the lower $\mathrm{P}_{\mathrm{O}_{2}}$ conditions showed limited recovery, and only to levels of feeding and ingestion comparable to those recorded in the early stages of hypoxia (Figs. 5A-C).

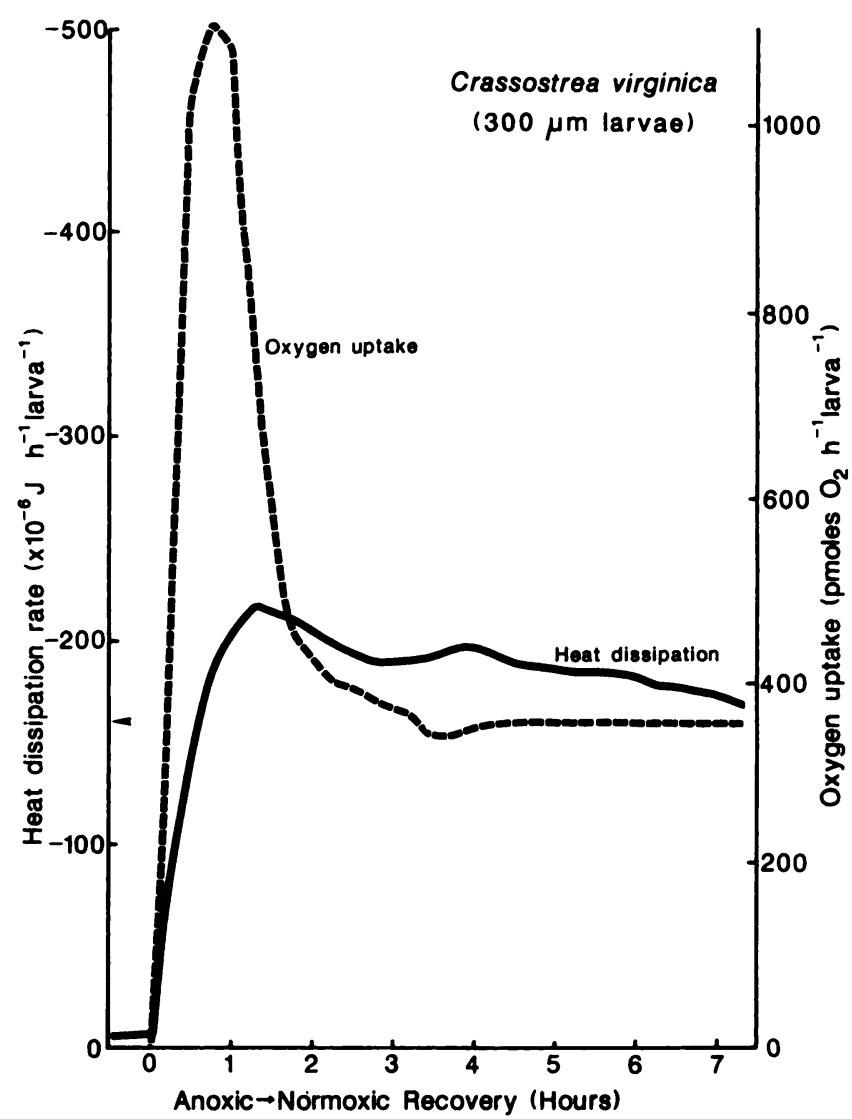

Figure 3. Recovery under normoxic conditions of rates of heat dissipation (solid line) and oxygen uptake (broken line) by pediveliger larvae of Crassostrea virginica following 11 hours of anoxia. 


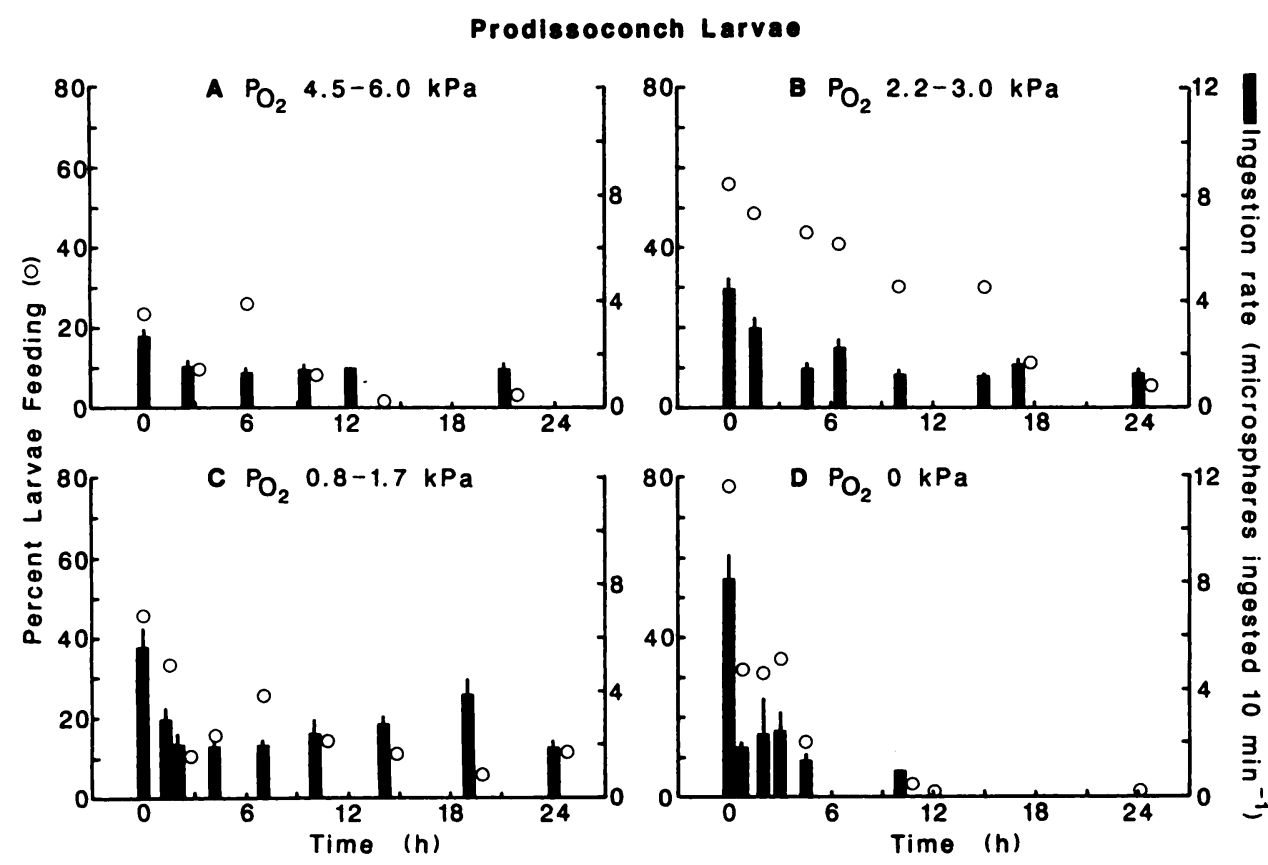

Figure 4. Effect of partial pressure of oxygen and duration of exposure on the feeding activity of prodissoconch larvae of Crassostrea virginica. Feeding activity is expressed in terms of the proportion of larvae feeding $(O)$ and their ingestion rates (number of microspheres ingested per 10 min.; histograms) during hypoxia (A, 4.5 to $6 \mathrm{kPa} ; \mathrm{B}, 2.2$ to $3 \mathrm{kPa} ; \mathrm{C}, 0.8$ to $1.7 \mathrm{kPa}$ ) and anoxia (D, $0 \mathrm{kPa}$ ).

\section{Discussion}

\section{Metabolic response to anoxia}

Oyster larvae tolerate anoxia, and this tolerance increases with larval development. This suggests that all larval stages have anaerobic metabolic pathways capable of sustaining life for a limited period of time under anoxic conditions. The increase in anoxia tolerance with larval development appears to be related to an ability to lower their rates of heat dissipation and thus conserve energy expenditure under anoxia. Figure 6 illustrates such a relationship $(r=0.99)$ in a plot of $\dot{Q}_{\text {anoxia }} / \dot{Q}_{\text {normoxia }}$ against the reciprocal of anoxia tolerance (1/MMT in $h$ ). The early larval stages maintain a high rate of heat dissipation (34\% of $\dot{Q}_{\text {normoxia }}$ ), at least during the initial $3 \mathrm{~h}$ of anoxia, whereas the later stages conserve energy by reducing anoxic rates of heat dissipation (3\% of $\left.\dot{Q}_{\text {normoxia }}\right)$. These differences in the level of $\dot{Q}_{\text {anoxia }}$ appear to correlate with the relative anoxic rates of ingestion (IR) by the different larval stages. After $2 \mathrm{~h}$ of anoxia, $\mathrm{IR}_{\text {anoxia }} / \mathrm{IR}_{\text {normoxia }}$ was $29 \%(2.5 / 8.5$, Fig. $4 \mathrm{D})$ for the prodissoconch larvae compared to $5 \%(2.25 / 42$, Fig. 5D) for the pediveliger larvae. Therefore, the higher anoxic metabolic rates by the prodissoconch compared to the pediveliger appear to be coupled to their higher levels of activity under anoxia (i.e., the observed swimming activity and measured feeding activity).
These results provide evidence of differences in the type of anoxibiosis sustained by different developmental stages of the species: 'functional anoxibiosis' in the early larval stages, characterized by high power output at the expense of efficiency, compared with 'environmental anoxibiosis' in later developmental stages, characterized by low power output and a relatively high efficiency of anoxic energy conversion (Gnaiger, 1983). If the prodissoconch larvae use glycogen in anaerobic metabolic pathways, then the relatively high anoxic rates of heat dissipation represent a very high cost, at least in terms of rate of glycogen use, because of the lower biochemical efficiency or ATP yield per glycosyl unit in anaerobic metabolism (4.71 mol ATP per mol of glycogen for the succinate pathway compared to $37 \mathrm{~mol}$ ATP per mol of glycogen for aerobic catabolism; Gnaiger, 1983). However, in contrast to the situation in adult bivalves, polysaccharides form a relatively small proportion (e.g., 2-3\% of organic matter) of the energy store in bivalve larvae (Holland and Spencer, 1973; Gabbott, 1976; Mann and Gallager, 1985) and in response to nutritional and environmental stress they use lipid (especially neutral lipid) and protein substrates. While lipid represents an efficient form of energy reserve for aerobic catabolism, because of its high energy content $\left(39.5 \mathrm{~kJ} \mathrm{~g}^{-1}\right)$, lipid cannot be used as a substrate for anaerobic metabolism. Bivalve larvae may prove to use protein and amino acids as energy substrates 


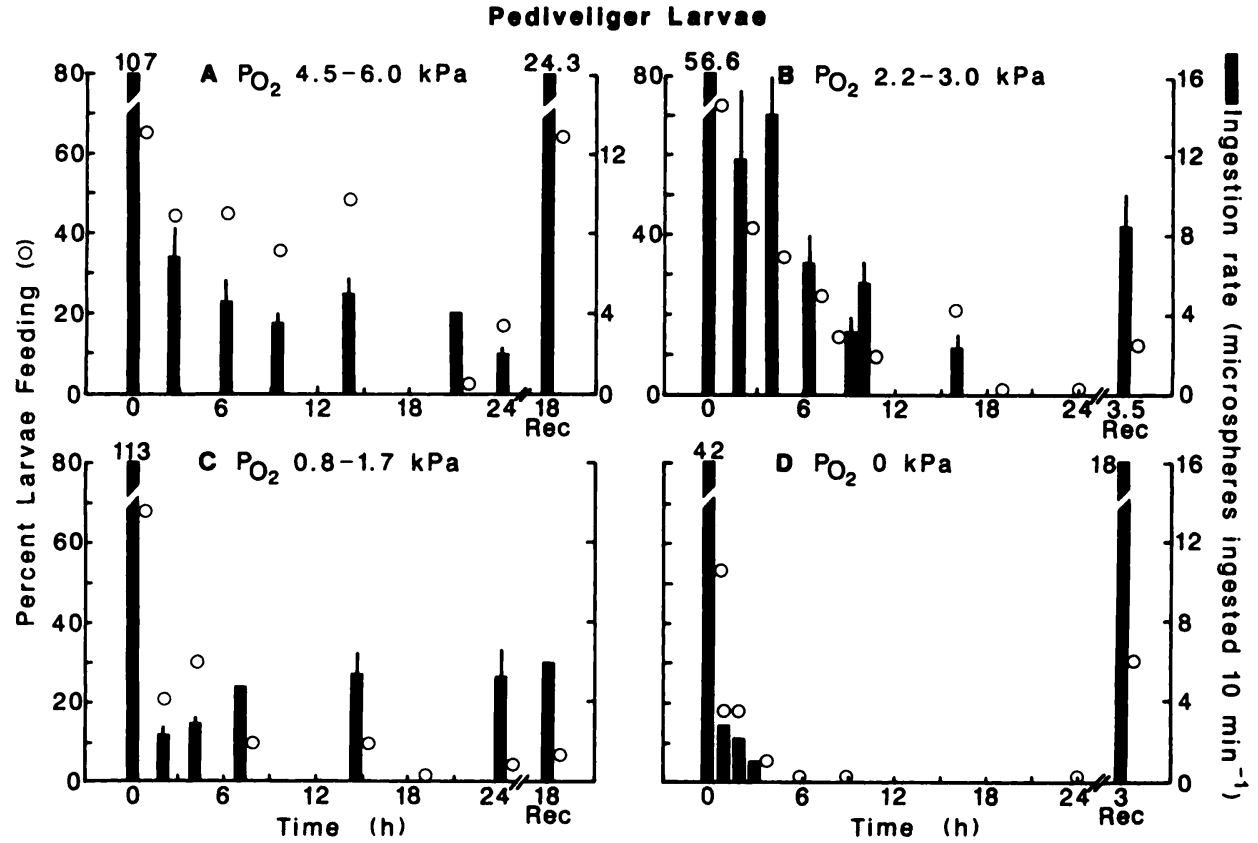

Figure 5. Effect of partial pressure of oxygen and duration of exposure on the feeding activity of pediveligers of Crassostrea virginica. Feeding activity is expressed in terms of the proportion of larvae feeding $(\mathrm{O})$ and their ingestion rates (number of microspheres ingested per $10 \mathrm{~min}$.; histograms) during hypoxia $(\mathrm{A}, 4.5$ to $6 \mathrm{kPa} ; \mathrm{B}, 2.2$ to $3 \mathrm{kPa} ; \mathrm{C}, 0.8$ to $1.7 \mathrm{kPa})$, anoxia $(\mathrm{D}, 0 \mathrm{kPa})$ and after 3 to $18 \mathrm{~h}$ of normoxic recovery.

for anaerobic metabolism, similar to sea anemones (Anthozoa), which use protein and accumulate nitrogenous end-products during anoxia (Ellington, 1980, 1982; Navarro and Ortega, 1984).

The relatively high anoxic rate of heat dissipation by prodissoconch larvae presumably enables the larvae to maintain their observed locomotory activity and to swim away from anoxic conditions (unpub. obs. and V. S. Kennedy, pers. comm.), but at considerable cost to their energy reserves, which are relatively small in the early developmental stages (Gabbott, 1976). These high costs are likely to result in a rapid depletion of energy reserves, thus limiting the anoxia tolerance of early larval stages.

This relationship between the anoxic rate relative to the normoxic rate of energy expenditure and anoxia tolerance is also apparent in interspecific comparisons with adult bivalves. For example, the clam (Mulinia lateralis), has a relatively high $\dot{Q}_{\text {anoxia }}$ (i.e., $97 \%$ of $\dot{Q}_{\text {normoxia }}$; Shumway et al., 1983) and is relatively intolerant of prolonged anoxia ( $c a .5$ days). The high anoxic energy demands of $M$. lateralis (confirmed by direct calorimetry; Shumway et al., 1983) are also related to the maintenance of locomotor and feeding activities under anoxia, which may be an adaptation to escape periodic burial in unstable, oxygen-deficient sediment. In contrast, the sessile mussel (Mytilus edulis) has a very low $\dot{\mathrm{Q}}_{\text {anoxia }}$ (i.e., $4 \%$ of
$\dot{\mathrm{Q}}_{\text {normoxia }}$; Widdows, 1987) which enables it to conserve energy and thus tolerate prolonged anoxia ( $c a .35$ days, Theede et al., 1969).

\section{Metabolic response to hypoxia}

Oyster pediveliger larvae and juveniles maintain rates of oxygen consumption down to relatively low $\mathrm{P}_{\mathrm{O}_{2}}$ values, as indicated by the $\mathrm{P}_{\mathrm{C}}$ values and $\mathrm{P}_{\mathrm{O}_{2}}$ at which the $\dot{\mathrm{N}}_{\mathrm{O}_{2}}$ is $50 \%$ of the normoxic $\dot{\mathrm{N}}_{\mathrm{O}_{2}}$ (Table I). Similar values have been recorded for adult Crassostrea virginica $(0.4$ g) under comparable conditions of $20^{\circ} \mathrm{C}$ and $14 \% \mathrm{~S}\left(\mathrm{P}_{\mathrm{c}}\right.$ of $8 \mathrm{kPa} ; \mathrm{P}_{\mathrm{O}_{2}}$ at $0.5 \dot{\mathrm{Q}}_{\text {normoxia }}$ of 3.4; Shumway and Koehn, 1982). The ability of the prodissoconch larvae to maintain their rates of oxygen uptake down to extremely low levels of $\mathrm{P}_{\mathrm{O}_{2}}$ appears to be a feature of very small individuals (such as the early larval stages) as a result of the high surface area to volume ratio and the short distance for oxygen diffusion (Herreid, 1980). Furthermore, low aerobic demands permit diffusion of oxygen to meet the needs of very small animals, as long as the animals are active and keep the surrounding water stirred. Oyster larvae maintained ciliary activity on the velum down to anoxic conditions, presumably to meet their swimming, respiratory, and feeding requirements.

There is no evidence of a major anaerobic component 


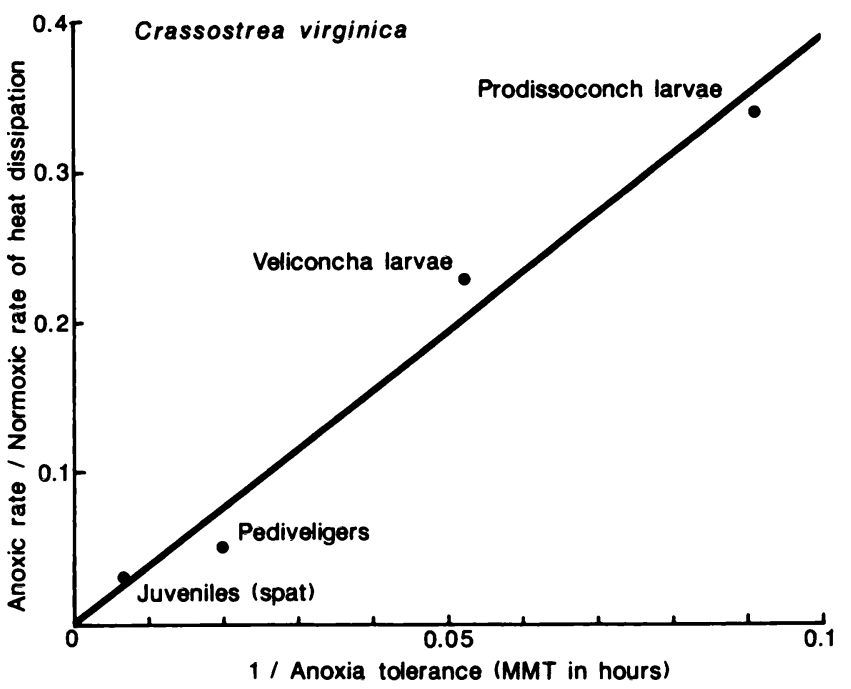

Figure 6. Relationship between anoxic rate/normoxic rate of heat dissipation and anoxic tolerance ( 1 /median mortality time in hours) of larvae and juveniles of Crassostrea virginica.

of total energy metabolism by larvae and juveniles of Crassostrea under hypoxic conditions. Measured oxycaloric equivalents are only slightly higher than theoretical values for totally aerobic catabolism from 20.33 down to $1.33 \mathrm{kPa}$, and this increase is not significant $(P<0.05)$ until $0.67 \mathrm{kPa}$ (Table II).

Recovery of pediveliger larvae ( $300 \mu \mathrm{m}$ shell length) after 11 hours of anoxia (Fig. 3) shows a similar metabolic response to that previously recorded for adult mussels, Mytilus edulis (Shick et al., 1986, 1988; Widdows, 1987). The overshoot in rate of heat dissipation was only $32 \%$, whereas the overshoot in oxygen uptake was $>300 \%$, resulting in an experimental oxycaloric equivalent of $-180 \mathrm{~kJ} \mathrm{~mol}^{-1} \mathrm{O}_{2}$. Experimental studies on adult bivalves have divided the overshoot in oxygen uptake (the 'oxygen debt payment') into two basic components, the metabolic component and the physical reoxygenation of water and oxygen stores within the valves of bivalves during the initial phase of normoxic recovery. This phenomenon is often recorded as a sudden 'oxygen sag' in the oxygen trace and coincides with the opening of the shell valves and the flushing out of deoxygenated water (ca. 15\% of oxygen overshoot; Shick et al., 1986). Such an 'oxygen sag' was also observed in the oxygen traces produced by the oyster larvae, and indicates that the reoxygenation of water within the shell valves of the larvae may form a significant contribution to the overshoot in oxygen uptake during the first $30 \mathrm{~min}$. However, even after accounting for the physical reoxygenation in adult $M$. edulis, the heat equivalent of oxygen uptake during early aerobic recovery exceeds the total heat dissipation rate, which results in an experimental oxycaloric equivalent of about $-200 \mathrm{~kJ} \mathrm{~mol}^{-1} \mathrm{O}_{2}$ (Shick et al., 1986; Widdows, 1987). Values significantly below -440 to $-480 \mathrm{~kJ} \mathrm{~mol}^{-1} \mathrm{O}_{2}$ indicate the conservation of heat in partially endothermic processes (biosynthesis), such as the restoration of high-energy phosphates, together with catabolic-anabolic coupled glyconeogenesis and the partial oxidation of the succinate that is accumulated by adult mussels during anoxia. However, the importance of these processes in the aerobic recovery of oyster larvae is unknown due to the absence of detailed information on the anaerobic metabolic pathways operating in larval stages and the accumulation of metabolic end products during anoxia.

\section{Feeding rate in response to hypoxia and anoxia}

The use of fluorescent microspheres provided an accurate method of quantifying ingestion rate, but may underestimate filtration rate when particles captured on the velum are rejected and not ingested (Gallager, 1988). In preliminary work using video microscopy, live larvae were observed feeding on the microspheres. These recordings showed that the microspheres were handled like algal cells and retained within the digestive system for many hours. They could also be clearly seen revolving in the crystalline style sac, thus indicating that polystyrene microspheres, which had been coated with an algal extract, were not being rapidly passed through the gut. This is in contrast to the observation of Robinson (1981) and Gallager (1988), who reported that Mercenaria mercenaria larvae can pass latex microspheres through their guts as fast as they are ingested. The mean ingestion rates of 55 microspheres larva ${ }^{-1} \mathrm{~h}^{-1}$ (prodissoconch) and 508 microspheres larva ${ }^{-1} \mathrm{~h}^{-1}$ (pediveliger) recorded for Crassostrea virginica, were similar to our measured rates of algal ingestion and the rates for Mercenaria mercenaria (86 Isochrysis cells $\mathrm{h}^{-1}$ for 2-day-old larvae of $100 \mu \mathrm{m}$ and 387 cells $h^{-1}$ for 10 day larvae of $234 \mu \mathrm{m}$ ) measured by Gallager (1988) using high-speed video microscopy.

The effect of hypoxia on the feeding and ingestion rates of oyster larvae generally reflects the relationship between $\mathrm{P}_{\mathrm{O}_{2}}$ and rates of heat dissipation by larvae. For example, a high proportion of the prodissoconch larvae were actively feeding and maintaining relatively high ingestion rates, at least during the initial $6 \mathrm{~h}$ at the three levels of hypoxia (Fig. 4A-C) and this corresponded with the maintained rates of heat dissipation down to extreme hypoxic conditions (Table I). The feeding response of the early feeding prodissoconch larvae therefore appears to be an all-or-none response, and this may reflect the low nutrient reserves in these early larval stages (Mann and Gallager, 1985), which necessitates that the larvae feed almost continuously. In contrast, the pediveligers 
showed a marked reduction in both the proportion of larvae feeding and their ingestion rates at more moderate levels of hypoxia (e.g., $2.2-3.0 \mathrm{kPa}$ ), and it was at these levels that the rate of heat dissipation also declined to $50 \%$ of the normoxic rate. Although feeding and ingestion rates by pediveligers were reduced, swimming activity observed in our study was maintained even after $6 \mathrm{~h}$ at $0.8 \mathrm{kPa}$, thus confirming the reported uncoupling of the swimming and feeding activity of the velum of $M$. mercenaria larvae (Gallager, 1988).

The increased sensitivity of pediveligers to hypoxia may reflect problems of oxygen diffusion associated with increasing body mass and therefore reduced surface area to volume ratio. Under hypoxic conditions the supply of oxygen to pediveligers is insufficient to meet the total metabolic demands of all processes. The $30-50 \%$ reduction in oxygen consumption by pediveligers at a $\mathrm{P}_{\mathrm{O}_{2}}$ of about $2-3 \mathrm{kPa}$ is not compensated by a major contribution from anaerobic metabolism. As a result, there is a reduction in the rates of 'non-essential' (at least in the short-term) and costly processes, such as the ingestion, digestion, and absorption of food and growth. In contrast, processes with relatively low costs, such as the ciliary activity of the velum (Silvester and Sleigh, 1984), are maintained under hypoxia, thus enabling larvae to escape and to resume feeding and growth when oxygen is more readily available. In concurrent experiments, V.S. Kennedy (pers. comm.) has demonstrated the importance of upward swimming as a means for larvae to avoid hypoxic conditions. This interpretation of hypoxic responses based on metabolic costs is supported by evidence of the partitioning of energy expenditure and the costs associated with different processes in the mussel (Mytilus edulis). The cost of ciliary activity of the gills represents $<3 \%$ of the total metabolic energy expenditure (TME), the cost of digestion and absorption of food forms is about $17 \%$ of the TME, and the cost of growth ranges from 0 to $30 \%$ of TME depending on ingestion rate (Widdows and Hawkins, 1989). Consequently, the energy conserved by markedly reducing the processes of digestion and absorption of food and growth, may largely account for the observed reduction in metabolic rate by larvae during hypoxia.

Therefore, the present study demonstrates good agreement between calorimetric, respirometric, feeding, and behavioral measurements on the larvae and juveniles of $C$. virginica in response to hypoxia and anoxia. It highlights the energetic changes associated with a change in behavior, from avoidance of anoxia in the early larval stage to tolerance in the later pediveliger larvae and juvenile oyster. It suggests that larvae are able to survive short-term (hours) hypoxia associated with low $\mathrm{O}_{2}$ in the Chesapeake Bay. However, although the larvae can toler- ate hypoxic conditions, their reduced feeding activity will reduce their growth rate and increase larval development times. This will expose the larvae for longer periods to predation by larval fishes and gelatinous carnivores, such as ctenophores (Mnemiopsis leidyi), hence reducing larval recruitment to the adult oyster population.

\section{Acknowledgments}

This work was supported by grant NA-86-AA-DSG042 from the National Sea Grant Program, NOAA, to the University of Virginia, grant NA-86-AA-SG006 to the University of Maryland, and the Visiting Scientist Program of the Virginia Institute of Marine Science (J.W.). We are grateful to J. S. Rainer for assistance.

\section{Literature Cited}

Coughlan, J. 1969. The estimation of filtration rate from the clearance of suspension. Mar. Biol. 2: 356-358.

Ellington, W. R. 1980. Some aspects of the metabolism of the sea anemone Haliplanella lucia (Verill) during air exposure and hypoxia. Mar. Biol. Lett. 1: 255-262.

Ellington, W. R. 1982. Metabolic responses of the sea anemone $B u$ nodosoma cavernata (Bose) to declining oxygen tensions and anoxia. Physiol. Zool. 55: 240-249.

Gabbott, P. A. 1976. Energy metabolism. Pp. 293-355 in Marine Mussels: Their Ecology and Physiology, B. L. Bayne, ed., Cambridge University Press, Cambridge.

Gallager, S. M. 1988. Visual observations of particle manipulation during feeding in larvae of a bivalve mollusc. In Zooplankton Behaviour Symposium, 1987, Georgia. Bull. Mar. Sci. 43: 344-365.

Gnaiger, E. 1983. Heat dissipation and energetic efficiency in animal anoxibiosis: economy contra power. J. Exp. Zool. 228: 471-490.

Herreid, C. F. 1980. Hypoxia in invertebrates. Comp. Biochem. Physiol. 67A: 311-320.

Holland, D. L., and B. E. Spencer. 1973. Biochemical changes in fed and starved oysters, Ostrea edulis L., during larval development, metamophosis, and early spat growth. J. Mar. Biol. Assoc. U. K. 53: 287-298.

Kemp, W. P., and W. R. Boynton. 1984. Spatial and temporal coupling of nutrient inputs to estuarine primary production: the role of particulate transport and decomposition. Bull. Mar. Sci. 35: 242247.

Mackiernan, G. B. 1987. Dissolved oxygen in the Chesapeake Bay: processes and effects. Maryland Sea Grant publication number UM-SG-TS-87-03. 177 pp.

Malone, T. C., W. M. Kemp, H. W. Ducklow, W. R. Boynton, J. H. Tuttle, and R. B. Jonas. 1986. Lateral variation in the production and fate of phytoplankton in a partially stratified estuary. Mar. Ecol. Prog. Ser. 32: 149-160.

Mann, R. 1986. Sampling of bivalve larvae. Pp 107-116 in North Pacific Workshop on Stock Assessment and Management of Invertebrates, G. S. Jamieson and N. Bourne, eds. Canadian Special Publication Fisheries and Aquat Sci. 92: Department of Fisheries and Oceans, Ottawa, Canada.

Mann, R., and S. M. Gallager. 1985. Physiological and biochemical energetics of larvae of Teredo navalis $\mathrm{L}$. and Bankia gouldi (Bartsch) (Bivalvia: Teredinidae). J. Exp. Mar. Biol. Ecol. 85: 211228.

Navarro, E., and M. M. Ortega. 1984. Amino acid accumulation 
from glucose during air exposure and anoxia in the sea anemone Actinia equina (L.). Comp. Biochem. Physiol. 78B: 199-202.

Newell, R. I. E. 1985. Physiological effects of the MSX parasite Haplosporidium nelsoni (Haskin, Stauber and Mackin) on the American oyster Crassostrea virginica (Gmelin). J. Shelfish Res. 5: 91-95.

Officer, C. B., R. B. Biggs, J. L. Taft, L. E. Cronin, M. A. Tyler, and W. R. Boynton. 1984. Chesapeake Bay anoxia: origin, development and significance. Science 223: 22-27.

Robinson, W. E. 1981. Quantification of ingestion by Mercenaria mercenaria (L.). veligers feeding on mixed suspensions of inert material and algae using microspectrofluorimetry. J. Moll. Stud. Suppl. 12A: $167-171$.

Seliger, H. H., J. A. Boges, and W. H. Biggley. 1985. Catastrophic anoxia in Chesapeake Bay in 1984. Science 228: 70-73.

Shick, J. M., E. Gnaiger, J. Widdows, B. L. Bayne, and A. de Zwaan. 1986. Activity and metabolism in the mussel Mytilus edulis $\mathrm{L}$. during intertidal hypoxia and aerobic recovery. Physiol. Zool. 59: 627-642.

Shick, J. M., J. Widdows, and E. Gnaiger. 1988. Calorimetric studies of behaviour, metabolism and energetics of sessile intertidal animals. Am. Zool. 28: 161-181.

Shumway, S. E., and R. K. Koehn. 1982. Oxygen consumption in the American Oyster Crassostrea virginica. Mar. Ecol. Prog. Ser. 9: 5968.
Shumway, S. E., T. M. Scott, and J. M. Shick. 1983. The effects of anoxia and hydrogen sulphide on survival, activity and metabolic rate in the coot clam, Mulinia lateralis (Say). J. Exp. Mar. Biol. Ecol. 71: 135-146.

Silvester, N. R., and M. A. Sleigh. 1984. Hydrodynamic aspects of particle capture by Mytilus. J. Mar. Biol. Assoc. U. K. 64: 859-879.

Taft, J. L., W. R. Taylor, E. D. Hartwig, and E. D. Loftus. 1980. Seasonal oxygen depletion in Chesapeake Bay. Estuaries 3: 242-247.

Theede, H., A. Ponat, K. Hiroki, and C. Schlieper. 1969. Studies on the resistance of marine bottom invertebrates to oxygen-deficiency and hydrogen sulphide. Mar. Biol. 2: 325-337.

Widdows, J. 1987. Application of calorimetric methods in ecological studies. Pp. 182-215 in Thermal and Energetic Studies of Cellular Biological Systems, A. M. James ed., Wright, Bristol.

Widdows, J., and A. J. Hawkins. 1989. Partitioning of rate of heat dissipation by Mytilus edulis into maintenance, feeding and growth components. Physiol. Zool. 62: 764-784.

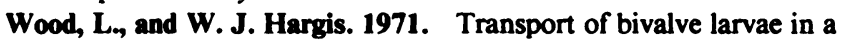
tidal estuary. Pp. 29-1 14. Fourth European Marine Biology Symposium, D. J. Crisp, ed., Cambridge University Press, London.

de $\mathbf{Z w a a n}$, A. 1983. Carbohydrate catabolism in bivalves. Pp 137175 in The Mollusca, Vol. 1. Metabolic Biochemistry and Molecular Biomechanics, P. W. Hochachka, ed. Academic Press, New York. 